\title{
FOREWORD PUBLISHING IN TANZANIA
}

\author{
C. S. L. CHACHAGE
}

The Background

Swahili is the national language of the United Republic of Tanzania and has been described as the 'most dynamic modern language of Africa' (Whiteley 1969:vii). Within Tanzania's borders one hundred and twenty different languages are spoken.

Most of these languages can be written using the [Roman] alphabet . . but before the coming of the Europeans only Swahili was written. Adherents of the Islamic religion were taught to read and to write verses of the Koran but a number of Swahili poets, mainly from the coastal area, also used Arabic script to write poetry. A rich collection of these old Swahili manuscripts in Arabic script $(25,000)$ exists at the University of Dar es Salaam and there are other collections in other centres abroad. (Bgoya 1984:3)

In 1884, the Germans colonised Tanganyika in order to open up the country to commerce and, as a preliminary requirement, establish law and order.

In 1888 there was a revolt against the Germans . . . and the military commissioner who suppressed it, one Herman von Wissman, advocated the use of the administrative structure practised by Arab rulers, which depended on agents called Akida as intermediaries between themselves and the population. The German Commissioner adopted this method and Swahili as the language through which commands were to be issued and responses received from all over the country. (ibid)

It thus became necessary to establish 'a local civil service for their administrative machinery'. As a result, they had to provide educational facilities (Cameron and Dodd 1970:54). By 1913 the Education Department was staffed by 24 Europeans and there were 99 government schools, 10 of which were principal schools and the rest elementary. At the same time there were 1,832 missionary schools with 108,550 pupils (Jones 1924). The British government later noted that the German education system was an 'instrument designed to meet a narrow, strictly vocational need' and that:

the results of their system are today evident in the large number of Natives scattered throughout the country who are able to read and write, and it must be admitted that the degree of usefulness to the administration of the natives of Tanganyika Territory is in advance of that which one has been accustomed to associate with British African Protectorates. (ibid.)

Already the demand for textbooks and other school materials to cater for these schools had been created. But the publishing and printing of such materials were mainly done in Germany as the missionary presses were small and the government had not yet established a printing press of its own.

The British took over the administration of Tanganyika in 1917 and found it to be a 
very difficult country to manage. Transport networks had been destroyed, the economy ruined and the environment damaged as a result of battles fought over its territory. Peasants had given up cash crop production, settlers and missionaries had abandoned farms, plantation production had been halted and the labour force virtually disbanded. British administrators were unhappy to find that the Swahili language had spread throughout the territory and was proving a unifying force between different tribal groups, for they lived with the fear of what they termed a Pan-Africanist Islamic renaissance in Tanganyika. They contemplated implementing a 'definite policy of encouraging strong and isolated tribal nationalism as one of the most effectual barriers against a Pan-African upheaval' (Lonsdale 1972:25-6). By the early 1920s their view was that it was wrong to 'Europeanise' Africans. The education system should be directed towards cultivating the 'African atmosphere, the African mind, the whole foundation of his race.' (TNA 7777/20). In this philosophy, an African was to be made to feel 'proud of being an African' (Cameron 1939).

British colonial education policy was based on separation of races. African, Asian and European schools were separate and different in every aspect as the races were destined to different places and functions in society. English was to be the language of the rulers. Hindi, Gujerati and English were to be the languages of the traders (Asians) and Swahili and the vernacular would be the languages of the African workers. Missionaries normally adopted the vernacular language of the area where they were based, and translated scriptures into those languages for local use. But Swahili was increasingly used as the medium through which general educational activities of the mission schools were carried out. (Bgoya 1984:4)

The development of Swahili into its present status of national language of Tanzania had begun.

African political associations emerged relatively slowly. The proto-organisation was the Tanganyika Territory African Civil Service Association founded in 1922; in the late 1920s came the Tanganyika African Association (TAA). They set a precedent for a supra-tribal rather than a tribal organization. In World War II an estimated 87000 Africans were conscripted. As in the 1914-18 conflict, missionaries were interned and church and educational work affected.

Change came faster in the postwar period and the main agent was the Tanganyika African National Union (TANU), founded in 1954. It built on the framework of the TAA, and a leading figure in ... the move to an explicitly political association was ... Julius Nyerere. (Murray 1981:189-190)

Independence came in 1961 to mainland Tanganyika and the United Republic of Tanzania was formed in 1964 when the newly independent countries of Tanganyika and the island of Zanzibar formed one nation.

\section{Mission Presses}

The first printing press in East Africa was established in Zanzibar in 1875 by Bishop Steere. This was the University Mission to Central Africa (UMCA) Printing Press. Other mission presses established in the next few years were the Freetown Mission Press in Mombasa in 1887, the Taveta Mission Press (TMP) at Tabora in 1890 and the Magila Press in Tanga in 1905. 
The mission presses began by publishing papers and books in Swahili, the complete Bible in Kiswahili being published in 1891 . Materials on the natural resources of Tanganyika, on medicine, animal husbandry and agriculture were produced, as were collections of folktales and stories, and memoirs, autobiographies and chronicles of East Africa. UMCA, the leading publisher of Swahili texts, produced a three part chronicle of the Kilindi people and the history of the rulers of Vuga by Abdallah bin Hemedi 'l-Ajjemy: Habari za Wakilindi in 1895, 1904 and 1907. In the same period the slave and ivory trader Tippu Tip published his autobiography: Maisha ya Hamed bin Muhammed el Murjebi, yaani Tippu Tip. In 1901 Velten, a former student of Carl Büttner published Safari za Wasuaheli, travel records related by a number of informants, including Selemani bin Mwenyi Chande who related an account of an ivory seeking expedition from the coast in Safari yangu ya Barra Afrika (My journey up-country in Africa) (see also Harries 1965) and Salim bin Abakari dictated three different accounts: Safari yangu ya Nyassa (My journey to Nyasaland), Safari yangu ya Ulaya toka Daressalama hatta Berlin (My journey to Europe, from Dar es Salaam to Berlin) and Safari yangu ya Russia na ya Sibirien (My journey to Russia and Siberia). In 1903 Velten published Desturi za Wasuaheli (The customs of the Swahili people) related by Mtoro Mwenyi Bakari of Bagamoyo who had also contributed to the 1901 volume (Bertoncini 1989:27-30). But some major oral literature from this period was only to be published by the East African Literature Bureau (EALB) in the 1950s and 1960s, for example a long epic poem on the resistance of the coastal peoples to the German invasion (Abdallah 1960) and Abdul Karim bin Jamaliddini's Utenzi wa Vita wya Maji Maji which records the resistance of the people of southern Tanganyika between 1905 and 1907 (1955/57).

By 1914 the German colonial government of Tanganyika was able to conduct much of its correspondence with village headmen in Swahili. This feature of German administration, as mentioned above, proved of great value to their successors, the British. The Report on the Territory for 1921, for example, stated that 'the late German system has made it possible to communicate in writing with every $A$ kida and village headman and in turn receive reports written in Swahili' (cited in Buell 1928). By now this process of literacy in Swahili had been accelerated by a flourishing press. Africans in Dar es Salaam and other places where there were missionary centres 'had been trained to set type and operate printing presses and missionary publications were circulating widely in Tanganyika before World War I' (Whiteley 1969:60; Scotton 1978:2).

Between the two World Wars the missionaries continued to dominate indigenous publishing activities and research work. They were also involved in standardising Swahili, following a meeting of all the East African countries called in 1925 by Governor Cameron. The meeting ended by proposing Swahili as a lingua franca for all four territories and in 1930 the Inter-territorial Swahili Language Committee was formed, charged with standardising orthography and dialectal forms for written Swahili (Whiteley 1969:79). Basically the Committee imposed the Kiunguja dialect as the standard form throughout East Africa. Among the best known missionary publishers and printers were Ndanda Mission Press (Mtwara), TMP (Tabora), Inland Press (Mwanza), Rumuli Press (Bukoba), Vuga Press (Tanga), Catholic Publishers (Dar es Salaam), White Fathers Press (Bukoba) and Benedictine Fathers Press at Peramiho. Although concentrating on the publication of religious tracts, most of these presses also published some educational material and some newspapers for general readership. These last were aimed at an African audience.

Most of the Swahili publications of this period were either translations from European school literature, such as Swahili versions of King Solomon's Mines, Alan Quartermain, Robinson Crusoe, Treasure Island or from Middle Eastern stories such as Burton's collection of The Arabian Nights. As these last were strikingly similar to Hekaya za Abu 
Nuwas (The Stories of Abu Nuwas) which had been circulating on the East African coast since the 8th century, they were extremely popular. They were published as Hekaya za Abunuwas na Hadithi nyingini (1935).

In the 1920s, Samuel Sehoza's Mwaka Katika Minyoro (A Year in Chains) was among the earliest prose works by Africans to be published. It was the story of the effects of the First World War on the African Christian community in Tanganyika. Africans who published in the 1920s and 1930s mostly published travel accounts or their own life stories, as did most European writers in Tanganyika at that time. In 1932, Martin Kayamba published both Tulivyoona na Tuliyofanya Ingereza (What They Saw and What They Did in England), and an article in Africa on the problems of the transition period among Africans. In 1936 he published An African in Europe, a further account of his life abroad. James Mbotela published Uhuru wa Watumwa (The Freeing of Slaves) in 1934 [1967], an autobiographical account of the son of a freed slave, which preached the virtues of obedience, love and kindness. Such writers were encouraged by the colonial administration. Shabaan Robert found it less easy to get his works published and tried to establish his own publishing house - Tanga Art and Literature - in the 1930s, but failed because of lack of finance.

With the 1930s, and a greater move towards the publishing of local history and literature, educated African intellectuals began to criticise a system of education whereby

you know that Dr Livingstone was the first European to see the River Zambezi or that it was Moses who led the Israelites out of Egypt, and yet you fail to know Kibi or Kiziba ... or how Omukama Ruhinda came to Karegwe and founded the Bahinda Empire ... (Katoke \& Rwechumbiza 1973:61).

Martin Kayamba, in African Problems (1936-7, reprinted 1948), wrote a systematic account of the thinking of 'modern Tanganyikans' of that time, setting out to demonstrate 'how fully the African, while remaining wholly African, could build towards a genuinely African future by wise study of and selection from all that the new forces of civilisation had to offer' (Kayamba 1948:7).

\section{British Colonial Presses}

Despite the setback of the First World War, by 1923 5,000 pupils were enrolled in 65 government schools. In addition, 115, 000 pupils were enrolled in 2,200 mission schools. Clearly educational needs were growing, but they were filled by publications produced in the main in England. Schoolbooks in use in England were imported and little or no adjustment made for differing needs in Africa.

In the meantime, English-based presses catered for a readership of mainly colonial administrators, missionaries, miners and settlers, and the few Africans who could read English. Works such as Young's Marching on Tanga (1917), Reid's Tanganyika without Prejudice (1934), and Joelson's The Tanganyika Territory (1920) were all produced in London. Many of the works were autobiographies and memoirs. Most offered 'the conventional picture - the author presented, gun in hand, with foot on the carcass of a lion or elephant' (Alexander 1936). Some wrote novels depicting their life, with European women suffering 'long hours of enforced inactivity' and so devouring this literature: 'good books, restful memories and happy plans for the future . . . the language, history and customs of native races surrounding her ...' (Dundas 1924:64-5). By the 1930s Tanganyika was known as Safariland and novelists such as Ernest Hemingway wrote of his own experiences in his autobiographical novel The Green Hills of Africa and his 
collection of stories entitled The Snows of Kilimanjaro.

A few early independent non-African publishers during the British colonial period were firms such as Smith, Mackenzie, Beauchamp and the Northern Province Press. With Britain occupying all four countries of East Africa, most printing and publishing, even for Tanganyika, was concentrated in Kenya, a settler colony with many European readers.

In 1937 a quarterly journal Tanganyika Notes and Records was established. Its aim was 'to promote the study of ethnology, history, geography, natural history and kindred sciences in relation to Tanganyika'. By 1957, it had 713 subscribers, of whom 143 were from Tanganyika. In its early days the contributions were dominated by European administrators, but among the Africans whose articles appeared before independence were: Martin Kayamba, Chief T. M. Marealle, A. B. Mtawa, Ole Kivasis (Justin Lemenye) and Petro Sh. Mtambo. President Nyerere became patron of the journal after independence and wrote: 'It is difficult for anyone to write about the history or the natural resources of our country without making copious use of these Records' (Tanzania Notes and Records 1966, no.64).

In 1948 the East African colonial governments set up the East African Literature Bureau (EALB). Its aims were to publish books for both an educational and a general readership; to produce popular magazines; to promote and encourage African authors; to establish lending library services; and to develop procedures for efficient book distribution. Behind this move lay the need for more reading materials for schools and a public thirst for wider general knowledge and information. In 1949, the Department of Education set up a textbook committee to review books for use in schools and colleges. By 1957, EALB had published 300 titles in various languages. However, the aim of encouraging African authors appeared secondary, as most of the early EALB authors were colonial administrators or British scholars.

British-based publishers also began to set up subsidiary organisations in Tanzania: first Macmillan, followed by Oxford University Press and Longman, Green and Company. All were anxious to supply copies of books already in use in British schools and widening educational needs promised increased local demand for such textbooks.

\section{Newspapers}

Between the two World Wars, mission presses produced newspapers for an African audience. Kiongozi (Leader), Limuli (The Torch) in Sukuma, Rumuli (The Torch) in Kihaya, and Katoliki (Catholic) were all produced by Catholic presses; Bendera ya Kikristo (Christian Flag) by Lutherans; Upangan wa Roho (Soul's Sword) by the Church Missionary Society (CMS) and Ija Woberere by the Swedish Mission. Several English language papers were produced by government or independent colonial presses: The Tanga Post, Dar es Salaam Times, and the Tanganyika Times were all founded in 1919; East Africa in 1920; Tanganyika Herald (in English and Gujerati) in 1929; The Planter, Tanganyika Review and Tanganyika Standard in 1932; and Tanganyika Opinion (English and Gujerati) and African Observer in 1934. Until the late 1930s only two Swahili government-sponsored newspapers were produced: Mamoleo (Today's Affairs) and Mwanafunzi (Learner), both published by the government printer. With the start of the Second World War, the government added more publications, in response to increased demand for news: Habari za Vita (News of the War) founded in 1939 and later renamed Habari za Leo (News of the Day); in 1941 The Tanganyika Herald hitherto published daily in English and Gujerati, added news in Swahili, as did Tanganyika Opinion.

More important, perhaps, than all these was the appearance of the first independent African newspaper in 1937: Kwetu (Our Home). The publisher and editor was Erica Fiah, 
well acquainted with the pan-African writings of black Americans and West Indians such as Marcus Garvey and George Padmore, as well as those of Solanke, JB Danquah, James Aggrey, etc. (Iliffe 1979:377; Wescott 1981). Kwetu's sub-title was 'The Key to Civilisation' and the aim of the paper was to do 'social and humanitarian work and establish contact between native and non-native communities' (Kwetu 7.12.1937). The paper's main focus was on general issues of racial discrimination, European control of political power, and economic exploitation. After World War II a new group of newspapers continued to promote radical ideas, spreading the thought that 'Tanganyika could be an independent country with a single widely-known language, Swahili, and one leader, an African' (Scotton 1978).

As independence approached, of eight million inhabitants, only 10 per cent of the population of Tanzania was literate, despite the growth of a strong press. In a typical rural scene, the local newspaper or news-sheet would be read aloud to an audience in the village square. All newspapers which championed the cause of independence would be received with enthusiasm. Radio was regarded as being controlled and manipulated by government. The political party TANU established a news-sheet Sauti ya TANU (The Voice of TANU) and from this grew the weekly TANU paper Mwafrika (African) with a circulation of 25,000 in 1958. Another popular newspaper was Zuhra:

written in conversational Swahili ... the editor got straight to the point early in his article and then pushed it without qualification in terms which even the semi-literate reader could understand easily ... Both Mwafrika and Zuhra were in great demand and their semi-literate readers would spell out each word to attentive listeners. (Scotton, 1978:11)

\section{Independence and Publishing}

The history of indigenous publishing in Tanzania has to be seen against the background of social, economic and political struggles towards independence and self-determination. Assessing the struggles for independence and the victory of the nationalist forces in his Maisha Yangu na Baada ya Miaka Hamsini, Shabaan Robert (1966) noted that the change from colonial rule to independence was viewed from two perspectives by Tanzanians: those who regarded it as the outcome of a long fight against the unequal distribution of wealth, profits and authority and those who viewed it as part of a worldwide movement for change.

Swahili can boast of nearly four centuries of written literature, mainly poetry. 'Swahili poetry has always addressed itself to the issues of the day and one poet's view of any issue was inspiration for another to agree and disagree or to shed light on the subject of the exchanges' (Bgoya 1984:6). Thus poetry has always been part of the popular culture. Three long poems written at the turn of the century were published between 1955 and 1957: Utenzi wa Vita vya Wadachi Kutamalaki Mrima (Epic Poem of the War against the Germans in the Mainland); Utenzi wa Kutawasifu Nabii (Epic Poem on the Prophet) and Utenzi wa Vita vya Maji Maji (A Poem on the Maji Maji War of Resistance) and by 1958 the first two were sold out and had to be reprinted by EALB.

A series of articles was published by Nyerere, the most famous of which was 'Ujamaa: the basis of African socialism' (1962). The ideas behind these articles found their expression in the Arusha Declaration of 1967. This committed Tanzania to building an egalitarian socialist society on the foundation of the past while at the same time extending herself to embrace modern technology. It was essentially a peasant form of socialism which emphasised rural development, and specifically communal (Ujamaa) villages. The main emphasis was on unity and development. 
Throughout the 1960s the production of monthly, weekly and daily newspapers increased. By 1967 there were four daily papers: The Standard (English, and foreignowned with a circulation of 17,000 copies); Ngurumo (Swahili, and independently owned with a circulation of 14,000 copies); The Nationalist (English, and owned by the ruling party, with a circulation of 6,000); and Uhuru (Swahili, and owned by the ruling party, with a circulation of 11,000$)$. The last two were established after independence. Uhuru replaced Sauti ya TANU in 1962 as a weekly paper, changing to daily in 1965 . The Nationalist was established in 1966. The Party was able to establish two dailies as a result of the foundation of the large printing press - Mwananchi Publishing Company (National Printing Company (NPC)) - but from a peak in 1967 the circulation figures began to fall. The Newspaper Ordinance of 1968 stipulated that the President could stop the publication of any newspaper if, in his opinion, that would be in the 'interest of the people' (Hansard April 30 1968). What remained was a press determined to 'exhort and preach'.

At independence, the lack of skilled manpower was one of the major problems confronting the country. A major expansion of the educational system was required. In 1961, the University College of Dar es Salaam was opened. From 1961 to 1976, enrolment in formal education at primary level increased from 471,000 to 2.2 million and at secondary level from 11,000 to 45,000 . The aim was to become self-sufficient in manpower by 1980 , though this goal has not yet been realised.

The expansion of education through the 1960s meant educational publishing became big business and it was mainly publishers and authors producing for the school market who reaped the large financial rewards. The battle for control of this lucrative market was usually won by foreign concerns. Even after independence, the education system remained essentially colonialist in outlook with, for example, literature students in secondary schools and at university dealing with a curriculum dominated by Shakespeare and the English poets. The first schools history of Tanzania (in English) was not published until 1969 (Kimambo and Temu), though a Swahili history of Tanzania had been published in 1965 (Nsekela). An 'Africanised' literature syllabus for schools appeared in 1972.

These changes meant that for the first ten years after independence, most books relevant to education were being published abroad, a situation which proved very lucrative for those foreign-based publishers able to supply the market. With the adoption of Swahili as the national language in 1962, its use as the medium of instruction in primary schools from 1968, the introduction of the first local university course in Swahili in 1968, and the creation of a Department of Swahili at the University of Dar es Salaam in 1970, publishing in Swahili began to grow. In 1974 a circular was issued directing all government officers 'to use Swahili in all official communications between Swahili speakers, and to use English only when addressing expatriate non-Swahili speakers' (Bgoya 1984:4).

Despite these measures, much publishing was still done outside East Africa, for example, Nyerere's Swahili versions of fulius Caesar and The Merchant of Venice (1963, 1969) were published for him by Oxford University Press rather than by the East African Literature Bureau. However the EALB did much to encourage local authors to publish both in English and in Swahili. In 1965, Andre Deutsch established the East African Publishing House (EAPH) in Nairobi with the aid of overseas funds. Headed by a former colonial officer, John Nottingham, its establishment was endorsed by the presidents of the three East African countries involved. It began to publish textbooks for schools, creative works, etc. It published the papers and books of the Historical Association of Tanzania (of the University of Dar es Salaam) and many other works on Tanzania, such as those by Tordoff, Ranger, Kimambo \& Temu, lliffe, Katoke \& Rwechumbiza, Sutton.

Tanzania Publishing House was formed by Macmillan, in partnership with the 
Tanzanian government in 1966 (a pattern adopted by Macmillan in several other newlyindependent African countries). At a time when the 'contract for a Primary Mathematics or English course for Tanzania could be worth several million shillings' being in partnership with the government obviously made it easier to 'make friends with the Ministry of Education officials' (Coulson 1979). It had been hoped that the establishment of TPH would be a way of disengaging from foreign publishers and thus of saving foreign exchange. In practice this did not happen, so in 1971 the Ministry of National Education decided to publish and reprint its own books, despite any lack of skill in this area.

The 1971 move by the Ministry was a devastating blow for the multi-national and foreign-based publishers. Most decided to leave Tanzania. Their profits had accrued from schools and textbook publishing and there was now little opportunity for this, apart from certain specialist areas such as the sciences. A few such as Oxford University Press, left offices which could liaise with Ministry of Education officials over course books for science and tertiary level institutions.

With the closure of the Kenya/Tanzania border in 1976, matters became more difficult. The East African Publishing House, which had printed most of its books in Nairobi, could no longer transfer the books to Tanzania. It had to split its operations and begin as a completely separate outfit in Dar es Salaam. Similarly, the East African Literature Bureau was split up and the Tanzanian section became Eastern Africa Publications Limited. Hitherto subsidised by the three East African governments, the new firm had to become a commercial organisation which generated its own profits. Stocks held in Kenya were unable to be exported to Tanzania. To date, the company has not fully recovered.

In a survey of publishers for the years 1972 to 1982 , ' 5 publications per year appeared to be an average number to qualify a publishing institution as "major" (Bgoya 1984:13). Five parastatal publishing houses qualified for this: Ministry of Education, Tanzania Publishing House (TPH), Dar es Salaam University Press (DUP), Tanzania Library Services (TLS), Eastern Africa Publications Limited (EAPL).

But despite the problems of those years, many more African authors were being published and in many and wider fields - literature, politics, history, agriculture, crafts, medicine, engineering, physics, soil sciences. Tanzania Publishing House (TPH) published authors such as Shivii (1972) and his criticisms of the Tanzanian type of socialism; novelists such as C.G. Mung'ong'o criticised the abuses of power in Tanzanian villages (1980); Liwenga (1980) wrote of popular discontent with the party and its leadership; and Mkufya (1977) wrote of urban problems and corruption. By the early 1980s, however, many such voices had been stilled: opposition, even if expressed through fiction, was not appreciated.

\section{Libraries}

The Tanzania Library Services Board Act was passed in 1963 'to promote, establish, equip and develop libraries in Tanganyika'. In 1975 a further act expanded the library system, extended the function of the Library Board, and put under its jurisdiction all public libraries. ('Public' was defined as any type of library to which a member of the public has access.) Other provisions of the act related to 'legal deposit, training of librarians, production and preservation of traditional literary works, etc.' (Bgoya 1984:35). The Board worked hard to fulfil the objectives of the act and in the ten years to $1974 \mathrm{had}$ increased its book stock from 49,000 to 900,000 . In addition, it operated a schools' mobile library service and provided rural mobile services as well. But with growing foreign exchange problems, the purchase of books produced abroad has proved more and more difficult. 
In addition, it has been calculated that over 90 per cent of all publishing activities in Tanzania in the 1970 s concentrated on the production of schools textbooks and that only 5 per cent of the books in any library were in Kiswahili.

In a bid to rescue this situation, Tanzania Library Services started its own publishing activities in the late 1970 s, concentrating mainly on the production of books for the general readership. It ran into the same problems as the other major publishers and found themselves unable to be effective in both librarianship and publishing.

The ultimate success of any library service is whether it reaches out to the whole country. The post-independence literacy campaigns which lowered illiteracy throughout Tanzania to less than 25 per cent were markedly successful.

But if the newly literate are not to lapse back into illiteracy, some form of library service will have to be established in each village. At present rural areas are served through the use of mobile libraries . . . but these vans are too few (5) and prone to breakdowns which make the service extremely irregular. (Bgoya 1984:36)

The Department of Adult Education within the Ministry of National Education has attempted to operate 2,500 village libraries, each housed in the offices of the ward headquarters of the ruling party. But with no qualified librarians to help staff them, the tendency is for the few books that are sent to each such library simply to disappear.

The University of Dar es Salaam Library was established in 1961 and shares with the Tanganyika Library Services the honour of being a legal depository for all printed matter produced in Tanzania. However, very few institutions adhere to these legal deposit regulations. In addition, like many university libraries in Africa, shortage of foreign exchange has meant a dearth of foreign-produced books in recent years and though a number of donor agency schemes have been launched they have not succeeded in restoring the number and quality of the books and periodicals that any major university library needs to have, not only for its students' needs, but for the research requirements of its staff.

\section{'Briefcase' Publishing}

From the beginning, and for obvious reasons, few publishers were brave enough to undertake the production of new work unless required for the school syllabus. Farouk Topan (1971:30) noted that the output of Swahili fiction had always been dictated by the demands of school syllabi and that it was depressing to record that a recent attempt at a mature type of fiction had been rejected because it was 'not fit for the classroom'. He noted that Swahili literature would only prosper if it got out of the 'school straitjacket' whether through the emergence of publishers who would act independently of possible school sales, or through newspapers encouraging the writing of short stories or serials. Not only adults suffered from this attitude: little or no children's fiction was produced. Having thrown out much of the colonial inheritance of children's literature, librarians lamented that they had been 'replaced with nothing'. The previous works may have 'been culturally irrelevant, but their replacement with nothing at all is even more dangerous' (ibid.).

Apart from government ministries, agencies and institutes and the five parastatal or major publishers there are a few private publishers such as Black Star Agencies, Africana Publishers, Swala Publishers, Press and Publicity Centre and Intercontinental Publishers which publish a range of material both inside and outside the textbook world.

In the late seventies, however, when the major publishers started facing a crisis, a number of author-publishers and family-based enterprises began to emerge, most of them 
as a response to the delays and general inefficiencies of the parastatal publishers. Mariy of these publishers do not have offices as such, but work from home. Hence they are known as 'briefcase' publishers. They publish mostly their own works but also sometimes those of other authors - crime novels, thrillers, romantic fiction, comics, cartoons, film magazines (Sani, Mcheshi, Fahari), and magazines and books which are socially and politically critical (Radi, Opinion, New Outlook). Some of them only come into existence to publish one or two books and then fade from existence. This may be because they have little understanding of the market and get into financial difficulties or it may be because, having published something successful, they choose to move on and invest their money in other businesses.

Publishers who concentrate on romance, crime and thrillers are Wamasa, Tajack Industries Ltd, Jakaranda Publications, Mcheshi Publications, Majira Publications, Grand Arts Promotion, BCI Publishers Ltd, Meza Publications, Ruvu Publishers, Heko Publishers as well as Press and Publicity Centre. Those who concentrate on socially and politically critical works are Grand Arts Promotion, Majira Publications, Pan African Publishers, as well as Press and Publicity Centre and Black Star Agencies.

The proliferation of small 'briefcase' publishers has created problems for booksellers who, when purchasing stock, have to go and search for each publisher individually, hence making the selling of books even more expensive. In 1978 there were around 80 independent publishers, now the number has virtually doubled. Their productions are mostly the work of young people, dependent for their living on how many copies of each book they can sell. They advertise widely in the popular press and usually sell through street vendors and informal contacts. In 1977 it was estimated that best-selling titles produced by publishers could sell 10,000 copies, however with rising inflation today the numbers would be much lower. Bookshops are mostly losing their share of this trade and its profits.

Many critics are dismissive of the type of literature generated in this way, labelling it as 'trash' or 'escapist', enjoyed by the primary or secondary school leaver who is unemployed, who read for the 'entertainment that he or she is denied in other ways' (Bgoya 1984). But the emergence of such literature is a social and literary phenomenon which cannot be dismissed so simply. Much of this so-called 'trash' literature supports post-independence struggles, condemns corruption and even exploitation, criticises social abuses, even combats sexism. Missionary publishers, such as Ndanda-Perhamiho, Benedictine Publications, TMP (Tabora), Central Tanganyika Press, Vuga Mission Press, have also joined in producing such literature. TMP, the Catholic publishers of Tabora, published Candid Scope's Honest to my Country, a book rejected by many of the larger publishers because of its criticism of the country's policies.

Independent publishers began to flourish at a time when the large parastatal publishers still believed that a 'book is an item of consumption that is only used by those who have attained a certain level of education and culture' and that 'if education is taken away from publishers they are left with a very small number of people who are conscious of the value of books or who are able financially to put money aside for buying them', as a result of 'lack of reading habits' due to the dominance of oral culture and illiteracy. It was believed that the

book market is essentially the school market. That is why public institutions, in particular, schools and colleges are the major customers of books and that is why all publishers orient their publishing programmes to the needs of public institutions (Bgoya 1978:2). 
But by 1984, when, for the first time, TPH attempted to sell books in the market places in Dar es Salaam, Bukoba and Zanzibar, it was admitted that the market for non-educational books, even serious ones, was quite big.

\section{Printing and Distribution}

Despite paper now being manufactured in Tanzania, the costs have rocketed. A two billion dollar mill was established in 1985, with the help of the Swedish International Development Agency (SIDA), Commonwealth Development Corporation (CDC), Norwegian Agency for International Development (NORAD) and the World Bank, amongst others. Its capacity was the production of 60,000 tons per annum, with a wide range of types of paper - newsprint, writing paper, kraftliners, photocopying paper, etc.; unfortunately from its inauguration in October 1985 it has been running at a loss. In April 1986 it was temporarily closed because of 'lack of orders': its paper was three times as costly as imported paper. (Daily News 23 May 1986) These problems are being ironed out but the mill has not yet reached its full capacity.

In 1972 UNESCO and UNICEF donated printing equipment to the government. However, not enough attention was given to the need to train staff in the production of books. Mpango wa Tanzania na UNICEF na UNESCO (MTUU) was formed as a department within the Ministry of Education, with the task of publishing all school books necessary for the education programme. To date they have been unable to fulfil this obligation and the books they have produced have been of poor quality. Although many printing presses exist in Tanzania, few are involved in the printing of books. Most concentrate on printing office stationery, exercise books and labels. Printpak, the largest of the book printing companies, also manufactures printing ink, sufficient not only for the needs of the other printers in Tanzania but exports ink to neighbouring countries. From time to time shortage of raw materials has affected the supply.

In 1967 the Ministry of Education decided that all distribution of books and other educational materials should be handled by Tanzania Elimu Supplies (TES). However, TES has proved itself unable to handle such large numbers, lacking an efficient infrastructure. The consequence has been that other routes have been tried, such as businessmen, in collaboration with Ministry of Education officials, buying large quantities of MTUU textbooks, selling them to district education officers and others at vastly inflated prices and resulting in profits for the wrong hands (Saiwaad \& Kamugisha 1988).

Although there are a large number of bookshops in Tanzania, only a few deal with books in any great number. Since selling educational books was confined to Tanzania Elimu Supplies, the number has contracted further. Bookshops which once flourished, but are now deprived of supplies, have been reduced to selling meagre amounts of stationery. Although TES 'is the most important book distributor' in Tanzania, it is 'also generally agreed that its service leaves a lot to be desired' (Bgoya 1984:28).

\section{Where the Future Lies}

An encouraging development in the last few years has been the formation of the Tanzania Writers Association (Umoja wa Waandishi wa Vitabu Tansania - UWAVITA) and an association of journalists and publishers of Tanzania (PATA). Both associations aim to promote writing, publishing, and the dissemination of printed matter in general. They were formed to try and resolve the problems of the publishing industry and in the past couple of years have organised conferences, workshops, discussions and book festivals. They have not, however, involved the bookshops in their programme, convinced as they 
are that their duty is to lobby government and the party. Some of the larger publishers go further and blame the 'briefcase' publishers and bookshop owners for their current problems. The President of PATA noted that publishers have inherited the 'best tradition of the Party and Government in furthering literacy, life-long education and development of people's culture ... not with parochial interests of a commercial organisation but with dedication in the transformation of turning to advantage . . . of science and technology' (Ministry of National Education 1988). In such a view the ordinary people, the real creators of culture, are assumed to be silent, simply dependent on those enlightened people and institutions which can transform them into 'cultured citizens'.

For publishing to solve its problems, it not only needs more funding, it also needs to abandon the view that it is a specialised concern and uphold the banner of criticism. It has to be the means through which ordinary men and women can express the fact that they are hungry or jobless, through which corruption, rhetoric and hypocrisy are exposed and condemned, through which public criticism can be voiced and issues debated .. all as in the Swahili poetry of earlier times. Publishers' problems are not simply technical, there is not just the need for a 'book development council', or 'a clear book policy from the government'. The publishing industry needs to free itself from the shackles of short-term profits and become the spokesman for the ordinary member of the public.

Department of Sociology University of Dar es Salaam

\section{Acknowledgements}

This is an edited and abridged version of an occasional paper written for the Department of Sociology of the University of Glasgow in May 1990. The author wishes to express his thanks to the numerous people who helped him with the original paper and to the British Council who fund the link programme between the Sociology Departments of the Universities of Glasgow, Hull and Dar es Salaam and the African Studies Centre of the University of Cambridge.

\section{REFERENCES}

Abdallah, bin Hamed. 1960. Utenzi wa Vita vya Wadachi kutamalaki Mrima. Dar es

Salaam: East African Literature Bureau.

Alexander, G. 1936. Tanganyika Memories: a judge in the Red Kanzu. Glasgow: Blackie. Bertoncini, E.Z. 1989. Outline of Swahili Literature. Leiden: Brill.

Bgoya, W. 1978. 'Rationalization of the publishing and printing industry'. Dar es Salaam:

Tanzania Publishing House [mimeo].

Bgoya, W. 1984. Books and Reading in Tanzania. Paris: UNESCO.

Buell, R.L. 1928. The Native Problem in Africa. London: Macmillan.

Cameron, D. 1939. My Tanganyika Service. London: Allen \& Unwin.

Cameron, J. and Dodd, W. 1970. Society, School and Progress in Tanzania. Oxford:

Pergamon Press.

Coulson, A. 1979. African Socialism in Practice. Nottingham: Spokesman.

Dundas, A. 1924. Beneath African Glaciers. London: Witherby.

Harries, L. 1965. Swahili Prose Texts. London: Oxford University Press.

Iliffe, J. (ed.) 1973. Modern Tanzanians. Nairobi: East African Publishing House.

Iliffe, J. 1979. A Modern History of Tanganyika. Cambridge: Cambridge University Press. Jamaliddini, Abdul Karim bin. 1955/57. [trs. W.H. Whiteley]. Utenzi wa Vita vya Maji

Maji. Fournal of the East African Swahili Committee.

Supplements 25/27. 
Joelson, F.S. 1920. The Tanganyika Territory: characteristics and potentialities. London: Fisher Unwin.

Jones, T.J. 1924. Education in East Africa. London: Edinburgh House.

Katoke, I.K. and Rwechumbiza, P. 1973. 'The administrator: Francis Lwamugira' in Iliffe (1973).

Kayamba, M. 1932. 'The modern life of the East African native'. Africa 5,1:50-60.

Kayamba, M. 1948. African Problems. London: Lutterworth.

Kimambo, I.N. and Temu, A.J. 1969. A History of Tanganyika. Nairobi: East African Publishing House.

Liwenga, G. 1980. Nyota ya Huzuni. Dar es Salaam: Tanzania Publishing House.

Lonsdale, J. 1972. 'Some origins of nationalism in Tanzania' in L. Cliffe and J. Saul (eds)

Socialism in Tanzania. Nairobi: East African Literature

Bureau.

Mbotela, J. 1967 [1934]. Uhuru wa Watumwa. Nairobi: East African Literature Bureau. Mkufya, W. 1977. The Wicked Walk. Dar es Salaam: Tanzania Publishing House. Mung'ong'o, C.G. 1980. Njozi Iliyopotea. Dar es Salaam: Tanzania Publishing House. Murray, J. 1981. Cultural Atlas of Africa. Oxford: Phaidon.

Nyerere, Julius. 1962. Ujamaa: the basis of African socialism. Dar es Salaam: TANU.

Nyerere, Julius. 1963. Fuliasi Kaizari. [Julius Caesar]. Dar es Salaam: Oxford University Press.

Nyerere, Julius. 1969. Mabepari wa Venisi. [The Capitalists of Venice]. Dar es Salaam: Oxford University Press.

Ranger, T.O. 1972. The African Churches of Tanzania. Nairobi: East African Publishing House.

Reid, E. 1934. Tanganyika without Prejudice. London.

Robert, S. 1966. Maisha Yangu na Baada ya Miaka Hamsini. London: Nelson.

Saiwaad, A.S. and Kamugisha, T.A.R. 1988. 'The publishing industry in Tanzania'. Dar es Salaam [mimeo].

Scope, Candid. 1981. Honest to My Country. Tabora: Tabora Mission Press.

Scotton, J.F. 1978. 'Tanganyika's African Press (1937-1960): a nearly forgotten preIndependence forum'. African Studies Review 16,1.

Shivji, I.G. 1972. The Silent Class Struggle. Dar es Salaam: Tanzania Publishing House. Sutton, J.E.G. 1966. The East African Coast: an historical and archaeological review.

Nairobi: East African Publishing House.

Tanganyika [ Tanzania] Notes and Records. 1937- . Dar es Salaam.

Tanzania National Archives (TNA). Dar es Salaam.

Tippu Tip. [trs. W.H. Whiteley]. 1966. Maisha ya Hamed bin Muhammed el Murjebi, yaani Tippu Tip. Nairobi: East African Literature Bureau.

Topan, Farouk. 1971. 'Swahili literature plays major social role'. Africa Report. 16,2, February 1971.

Tordoff, W. 1967. Government and Politics in Tanzania. Nairobi: East African Publishing House.

Velten, C. 1901. Safari za Wasuaheli. Göttingen.

Velten, C. 1903. Desturi za Wasuaheli. Göttingen.

Wescott, N.J. 1981. 'An East African radical: the life of Erica Fiah'. Fournal of African History 22.

Whiteley, W.H. 1969. Swahili: the rise of a national language. London: Methuen.

Young, F.B. 1917. Marching on Tanga. London: Collins. 